\title{
The influence of urban form and socio-demographics on active transport: A 40-neighborhoods study in Chengdu, China
}

\author{
ChengHe Guan \\ New York University Shanghai \\ chenghe.guan@nyu.edu
}

\author{
Ann Forsyth \\ Graduate School of Design \\ Harvard University \\ aforsyth@gsd.harvard.edu
}

\begin{abstract}
In China, a centralized planning culture has created similar neighborhoods across the country. Using a survey of 1,048 individuals conducted in 2016 in Chengdu-located in a carefully conceptualized typology of neighborhood forms-we analyzed the associations between individual and neighborhood characteristics and active or nonmotorized transport behavior. Using several multiple logistic and multilevel models, we show how neighborhoods were categorized and how the number of categories or neighborhood types affected the magnitude of the associations with active transport but not the direction. People taking non-work trips were more likely to use active compared with motorized modes in all neighborhood types. Neighborhood type was significant in models but so too were many other individual-level variables and infrastructural and locational features such as bike lanes and location near the river. Of the 3-D physical environment variables, floor area ratio (a proxy for density) was only significant in one model for nonwork trips. Intersection density and dissimilarity (land-use diversity) were only significant in a model for work trips. This study shows that to develop strong theories about the connections between active transport and environments, it is important to examine different physical and cultural contexts and perform sensitivity analyses. Research in different parts of China can help provide a more substantial base for evidenceinformed policymaking. Planning and design recommendations were made related to active transport need to consider how neighborhoods, built environments, and personal characteristics interact in different kinds of urban environments.
\end{abstract}

Keywords: Urban form, active transport, nonmotorized transport, neighborhood type, China

\section{Article history:}

Received: November 30, 2019

Received in revised form: March

12, 2020

Accepted: July 8, 2020

Available online: October 29,

2020

Copyright 2020 ChengHe Guan \& Ann Forsyth

http://dx.doi.org/10.5198/jtlu.2020.1697

ISSN: $1938-7849$ | Licensed under the Creative Commons Attribution - Noncommercial License 4.0

The Journal of Transport and Land Use is the official journal of the World Society for Transport and Land Use (WSTLUR) and is published and sponsored by the University of Minnesota Center for Transportation Studies. 


\section{Introduction}

Chinese cities are experiencing rapid growth and Chinese urban neighborhoods are undergoing substantial change ( $\mathrm{Su}, 2014$; He \& Lin, 2015; Srinivasan, Guan, \& Nielsen, 2019; Guan et al., 2020). The government has launched a series of planning policies to promote active transport; for example, the Ministry of Housing and Urban-Rural Development and the National Development and Reform Commission's guidelines and suggestions for building pedestrian and bike networks (China Sustainable Transportation Center, 2012). However, numbers of private motor vehicles continue to increase (123 million in 2015) and the share of active modes has continued to fall (National Bureau of Statistics of China, 2016).

In this evolving context, understanding travel behavior is all the more important. What is walking and cycling behavior like in different types of neighborhoods in transforming Chinese cities? How does this behavior — dubbed active transport (AT) or non-motorized transport (NMT) — vary with individual-level socio-demographic characteristics and neighborhood physical characteristics? Using a survey of 1,048 individuals conducted in 2016 in Chengdu, a carefully conceptualized typology of neighborhood forms, and regression models, we analyzed the associations between individual and neighborhood characteristics and active transport behavior. Generally, when examining neighborhood form, certain variables were significant for work trips by active transport while others were significant for non-work trips. Multiple models, using different typologies of neighborhoods, and different measures of active transport generally converged on similar findings.

With some exceptions, most prior studies have explored urban form and active transportation in China's coastal cities, such as Beijing and Shanghai, and a number were conducted before extensive motorization (Pan, Shen, \& Zhang, 2009; Zhao \& Chai, 2013; Feng, Dijst, Wissink, \& Prillwitz, 2014; Shen, Chai, \& Kwan, 2015; Wu, Chen, \& Jiao, 2019). Some have examined active transportation in the context of multiple socio-demographic variables and urban form variables at the neighborhood level, as well as location within the metropolis, but few have also looked at neighborhood types. Neighborhood types are important in China because nationally there are many parallels among developments from similar periods, and these neighborhoods mix a bundle of physical and social characteristics (Wang \& Zhou, 2017; Hu, Yang, Yang, Tu, \& Zhu, 2019; Guan, Srinivasan, \& Nielsen, 2019). By examining individual and neighborhood factors, this paper provides a more nuanced view of the evolving landscape of active transport in China.

The paper first examines how neighborhoods have been classified in prior work on active transport in China and contributes a refined typology: traditional, work unit, commodity, and affordable housing. Neighborhood types had different socio-demographic, physical environment, and transportation profiles. In regressions some key socio-demographic variables were associated with active transport across all models- age increased such travel and car ownership decreased it. Other socio-demographic and economic variables differed in sign and significance by trip purpose and model complexity. Among the four neighborhood types, in adjusted models, active transport had the highest odds for non-work trips in work unit neighborhoods and for work trips in affordable housing. However, key variables often thought to be associated with more walking for transport had inconsistent or counter-intuitive findings. For example, higher building floor area ratios (FARs, a proxy for population density) were either not significant in adjusted models or led to less active transport for non-work purposes (see also Sakar, Webster, \& Gallacher, 2017; Lu, Xaio, \& Ye, 2016).

Our findings confirm prior Chinese studies where people in traditional mixed use and work-unit types of neighborhoods had shorter trips (Shen et al., 2015), though in the high-income mixed use areas in this study this did not necessarily lead to more active transportation. In this Chinese case certain neighborhood types increased the odds ratio of choosing active transport even after adjusting for income 
and other socio-demographic variables, though this was not the case for all types even though they varied substantially in their historical development, physical character, and demographics. Counterintuitive findings about some built environmental variables add to this complexity. These findings show that it is important for research to examine a wide range of cultural contexts and built environments, as theories and concepts developed in one context may not always be applicable elsewhere. Planning and design recommendations can then consider how neighborhoods, built environments, and personal characteristics interact to support active transport or the reverse.

\section{Background}

\subsection{Neighborhoods, households, individuals, and active transport}

Many factors influence travel mode decisions. In the area of active transport, theories from two main bodies of work frame researchers' understandings - utility-maximizing theory in transportation and social ecological models from public health (Krizek, Handy, \& Forsyth, 2009; Baranowski, Cullen, Micklas, Thompson, \& Baranowski, 2003). Utility maximization focuses on the decision to make a trip; one that maximizes utility (minimizes time and monetary cost, and potentially brings benefits). This is influenced by personal attitudes, preferences, household characteristics, and social networks. Social ecological models similarly emphasize how behavior is influenced by multiple factors- "individual, interpersonal, and environmental" (Krizek et al., 2009; Yang, 2010).

In most theories about the active travel modes of walking and cycling, the residential neighborhood is seen as being an important environment that can enable or constrain individual and household transportation choices (Boussauw \& Witlox, 2011; Lin, 2018; Nilsson \& Delmelle, 2018). It can do this physically (are there paths?), economically (what are the relative costs of different modes?), and socially and culturally (how are different modes perceived?). Neighborhoods are of course set within a broader context - physical, economic, social, cultural, and institutional—but can be a key point of variation with metropolitan areas.

Several review or conceptual papers help specify how this occurs. An early paper by Cervero and Kockelman (1997) proposed that active travel could be influenced by changing the built environment variables of residential density, land-use diversity, and design. Ewing and Cervero (2010) later expanded these 3Ds to six, adding demand management, destination accessibility, and distance to transit. In a review of walking and cycling for transportation, Forsyth and Krizek (2010) summarized these into hard and soft measures: physical or hard infrastructure versus soft approaches such as pricing, programming, and education or social marketing. Recent reviews of multiple studies in this area have pointed to a general finding that the residential neighborhood matters but studies vary in which aspects of the neighborhood environment matter and how much it matters relative to other environments such as workplaces (Boussauw \& Witlox, 2011; Cerin, Nathan, van Cauwenberg, Barnett, \& Barnett, 2017; Cervero, 2013; Day, 2016; D’Haese et al., 2015; Smith et al., 2017; Wang \& Zhou, 2017; Guan et al., 2019). Typically, other factors — individual, interpersonal, regional, societal—are also found to be crucial. Importantly for this study, broad cultural factors affect both physical and social environments, as well as individual perceptions and behaviors, making it important to study active transport in a variety of contexts (D’Haese et al., 2015; Day, 2016).

\subsection{Neighborhoods}

In China a centralized planning national policy has created an identifiable range of neighborhoods across the country. A number of authors have developed classifications of these neighborhoods. Table 
1 presents several of these developed for studies of active transport and wellbeing. The typologies cover similar ground, though placing different emphases on urban form, housing sources (tenure, market status), and construction period.

Table 1. Neighborhood typology comparison for studies of active transport

\begin{tabular}{|c|c|c|c|c|c|c|}
\hline Studies & $\begin{array}{l}\text { Pan et al. } \\
(2009)\end{array}$ & $\begin{array}{l}\text { Zhao and } \\
\text { Chai (2013) }\end{array}$ & $\begin{array}{l}\text { Feng et al. } \\
(2014)^{4}\end{array}$ & $\begin{array}{l}\text { Shen et al. } \\
(2015)\end{array}$ & $\begin{array}{l}\text { Wu et al. } \\
(2019)\end{array}$ & This paper \\
\hline $\begin{array}{l}\text { Main } \\
\text { geography }\end{array}$ & Shanghai & Beijing & Nanjing & $\begin{array}{l}\text { Beijing (Sub- } \\
\text { urbs) }\end{array}$ & Shanghai & Chengdu \\
\hline $\begin{array}{l}\text { Typology } \\
\text { dimensions }\end{array}$ & $\begin{array}{l}\text { Period/ urban } \\
\text { form/ housing } \\
\text { sources }^{1}\end{array}$ & $\begin{array}{l}\text { Period/ hous- } \\
\text { ing sources }{ }^{1}\end{array}$ & $\begin{array}{l}\text { Period/ hous- } \\
\text { ing sources }{ }^{1}\end{array}$ & $\begin{array}{l}\text { Period/ hous- } \\
\text { ing sources }{ }^{1}\end{array}$ & $\begin{array}{l}\text { Period/ hous- } \\
\text { ing sources/ } \\
\text { location }\end{array}$ & $\begin{array}{l}\text { Period/ hous- } \\
\text { ing resources } 1 / \\
\text { location }^{2}\end{array}$ \\
\hline \multicolumn{7}{|c|}{ Typologies below } \\
\hline \multicolumn{7}{|c|}{ OLDER TYPES } \\
\hline Traditional & Li-long $^{5}$ & & Mixed use & & Historical & $\begin{array}{l}\text { Mixed use/ } \\
\text { Xiang-zi5 }\end{array}$ \\
\hline \multirow[t]{2}{*}{$\begin{array}{l}\text { Work unit/ } \\
\text { pre-reform }\end{array}$} & & Work unit & $\begin{array}{l}\text { Danwei (work } \\
\text { unit) }\end{array}$ & Work unit & $\begin{array}{l}\text { Old Worker- } \\
\text { Village (1950s) }\end{array}$ & Work-unit \\
\hline & $\begin{array}{l}1970 \mathrm{~s} / 80 \mathrm{~s} \\
\text { planned }\end{array}$ & & & & $\begin{array}{l}\text { Older Neigh- } \\
\text { borhoods }\end{array}$ & \\
\hline \multicolumn{7}{|c|}{ RECENT TYPES } \\
\hline $\begin{array}{l}\text { Commodity } \\
\text { housing }\end{array}$ & Commodity & $\begin{array}{l}\text { Commodity } \\
\text { housing }\end{array}$ & Commodity & $\begin{array}{l}\text { Commodity } \\
\text { housing }\end{array}$ & $\begin{array}{l}\text { Commercial } \\
\text { Residential/ } \\
\text { Deluxe proper- } \\
\text { ties }\end{array}$ & $\begin{array}{l}\text { Commodity } \\
\text { housing }\end{array}$ \\
\hline $\begin{array}{l}\text { Relocated } \\
\text { housing }\end{array}$ & & & & $\begin{array}{l}\text { Relocated } \\
\text { housing }\end{array}$ & & Affordable \\
\hline $\begin{array}{l}\text { Affordable } \\
\text { housing }^{3}\end{array}$ & & $\begin{array}{l}\text { Affordable } \\
\text { housing }\end{array}$ & & $\begin{array}{l}\text { Affordable } \\
\text { housing }\end{array}$ & & Affordable \\
\hline
\end{tabular}

1 "Housing sources" includes tenure (rent or own), market status (affordable, market rate), and whether the housing is provided by an employer (work unit) (Wang \& Zhou, 2017, 579).

2 Location generally relates to distance to the city core.

3 In China much government affordable housing has some form of ownership though some is rental.

4 Feng et al.'s analysis was at Traffic Analysis Zone level

5 Li-nong is a residential community centered on several interconnected lanes in Shanghai; Xiang-zi in Chengdu is loosely equivalent to Li-nong.

The four types of neighborhoods used in this paper reflect this prior work. First are traditional mixed use areas, developed before centralized planning and often quite valuable due to their central location. Second are work units, from the Mao period, dominated by parallel-block arrangements. However, urban redevelopment has reshaped many work-unit neighborhoods to be high-density and high-rise in prime locations. Third is commodity housing, including both high-rise and low-rise areas. Finally is affordable housing. This includes resettlement housing, a product of rapid urban growth and land use rights conversion, and other large scale affordable ownership developments (Zhao \& Chai, 2013).

\subsection{Chinese studies of neighborhoods and active transport}

Research on active transport and built environments is a growing field in China (Day, 2016; Wang \& 
Zhou, 2017). This literature is important because of the distinctive housing forms in China (e.g., highdensity superblock arrangements) and the fast pace of urban transformation in recent decades (Feng et al., 2014; Wang \& Zhou, 2017). However, most work to date has focused on coastal Chinese cities rather than the hinterland (see Table 2). While studies of neighborhood and housing types is a vibrant subfield, only a small subset of these studies has specifically examined active transport. In addition, several studies compare people in work units and other housing but use large random surveys, and large spatial zones, rather than focusing on the built environment of specific neighborhoods (e.g., Wang $\&$ Chai, 2009; Zhao, Lu, \& Roo, 2011; Feng et al., 2014).

Table 2. Studies of neighborhoods and active transport in China

\begin{tabular}{|c|c|c|c|c|c|c|}
\hline & $\begin{array}{l}\text { Pan et al. } \\
(2009)\end{array}$ & $\begin{array}{l}\text { Zhao and } \\
\text { Chai (2013) }\end{array}$ & $\begin{array}{l}\text { Feng et al. } \\
(2014)\end{array}$ & $\begin{array}{l}\text { Shen et al. } \\
(2015)\end{array}$ & $\begin{array}{l}\text { Wu et al. } \\
(2019)\end{array}$ & This paper \\
\hline $\begin{array}{l}\text { N people/ } \\
\text { trips }\end{array}$ & $1,709 / \mathrm{na}$ & $652 / \mathrm{na}$ & $3,894 / 4735$ & $709 /$ na & $2838 / \mathrm{na}$ & $1,048 / 2,397$ \\
\hline Population & Residents & $\begin{array}{l}\text { Households } \\
\text { in each of the } \\
\text { six neighbor- } \\
\text { hoods; } 16+\text { age }\end{array}$ & $\begin{array}{l}\text { Residents in } \\
\text { traffic Analysis } \\
\text { Zones (TAZ) }\end{array}$ & $\begin{array}{l}480 \text { com- } \\
\text { munity } \\
\text { residents and } \\
229 \text { company } \\
\text { employees; } \\
14+\text { age }\end{array}$ & Residents & $\begin{array}{l}\text { Residents } \\
\text { longer than a } \\
\text { year with age } \\
\text { of } 18 \text { to } 70 \text { (in- } \\
\text { cluding urban } \\
\text { migrants) }\end{array}$ \\
\hline $\begin{array}{l}\text { Data } \\
\text { collection } \\
\text { method }\end{array}$ & $\begin{array}{l}\text { On-street } \\
\text { interview; } \\
\text { intercept (not } \\
\text { random) } \\
\end{array}$ & $\begin{array}{l}\text { Random } \\
\text { household sur- } \\
\text { vey (question- } \\
\text { naire) }\end{array}$ & $\begin{array}{l}\text { Travel survey } \\
\text { with 1-day } \\
\text { diary }\end{array}$ & $\begin{array}{l}\text { Activity travel } \\
\text { survey on } \\
\text { site; an online } \\
\text { survey }\end{array}$ & $\begin{array}{l}\text { Distributed by } \\
\text { community } \\
\text { officials door- } \\
\text { to-door }\end{array}$ & $\begin{array}{l}\text { On-site inter- } \\
\text { view }\end{array}$ \\
\hline $\begin{array}{l}\text { Analysis } \\
\text { methods }\end{array}$ & $\begin{array}{l}\text { Multiple logis- } \\
\text { tic regression }\end{array}$ & $\begin{array}{l}\text { Multivariate } \\
\text { regression and } \\
\text { geo-visualiza- } \\
\text { tion }\end{array}$ & $\begin{array}{l}\text { Multiple-logis- } \\
\text { tic regression }\end{array}$ & $\begin{array}{l}\text { Ordered logit } \\
\text { model and } \\
\text { ANOVA }\end{array}$ & $\begin{array}{l}\text { Multiple logis- } \\
\text { tic regression }\end{array}$ & $\begin{array}{l}\text { Multiple logis- } \\
\text { tic regression, } \\
\text { and ANOVA }\end{array}$ \\
\hline $\begin{array}{l}\text { Outcome } \\
\text { variable(s) }\end{array}$ & $\begin{array}{l}\text { Transit, driving } \\
\text { vs walk/cycle } \\
\text { trips }\end{array}$ & $\begin{array}{l}\text { Travel time } \\
\text { and leisure } \\
\text { time }\end{array}$ & $\begin{array}{l}\text { Transit, motor- } \\
\text { ized, cycle vs } \\
\text { walk trips }\end{array}$ & $\begin{array}{l}\text { Travel time } \\
\text { and location }\end{array}$ & $\begin{array}{l}\text { Primary shop- } \\
\text { ping travel } \\
\text { mode }\end{array}$ & $\begin{array}{l}\text { Active trans- } \\
\text { port-NMT } \\
\text { mode choice, } \\
\text { and any NMT } \\
\text { in a day }\end{array}$ \\
\hline $\begin{array}{l}\text { Scale/ } \\
\text { geography }\end{array}$ & $\begin{array}{l}\text { Four neighbor- } \\
\text { hoods from } \\
\text { inner and } \\
\text { outer city of } \\
\text { Shanghai }\end{array}$ & $\begin{array}{l}\text { Six neighbor- } \\
\text { hoods, in } \\
\text { Beijing }\end{array}$ & $\begin{array}{l}\text { Eight districts, } \\
\text { approx. } 150 \\
\text { people ran- } \\
\text { domly sampled } \\
\text { from each TAZ }\end{array}$ & $\begin{array}{l}\text { A suburban } \\
\text { new town } \\
\text { in Beijing } \\
\text { (Shangdi- } \\
\text { Qinghe) }\end{array}$ & $\begin{array}{l}\text { Five neighbor- } \\
\text { hood types, } \\
21 \text { neighbor- } \\
\text { hoods, in } \\
\text { Beijing }\end{array}$ & $\begin{array}{l}\text { Four types, } 40 \\
\text { neighborhoods } \\
\text { in Chengdu }\end{array}$ \\
\hline
\end{tabular}

One of the most influential empirical studies recognizing the importance of neighborhood type on active transport in China, Pan et al. (2009) analyzed a survey of 1,709 individuals conducted in four neighborhoods of Shanghai in 2001. The study compared one traditional-styled "Li-nong" area built in the 1930s-1940s with two planned communities built in the 1970s-1980s and one commodity residential block built in the 1990s. The results showed that residents in what they termed the pedestrian/ cyclist-friendly neighborhoods travelled shorter distances than in other neighborhoods, making active transport modes feasible. Pedestrian and cycling friendly areas were defined in terms of population density, diversity of land use, block size, road density, and location relative to the city center and transit; regression models controlled for income and household features. Pan et al.'s survey was conducted while 
Shanghai and the rest of China still had low levels of car ownership (Pan et al.'s neighborhoods averaged from 4 to 13 cars per 100 households (p. 282)). As China has moved toward a more car-dependent society, neighborhood forms may interact differently with travel behavior. In addition, affordable communities and mid- to high-rise affordable housing developments have become prevalent type of neighborhoods since the late 1990s.

Zhao and Chai (2013) compared residents in affordable housing neighborhoods with work-unit and commodity housing neighborhoods in Beijing. They drew upon data from a 48-hour activity diary survey conducted in $2007(\mathrm{~N}=652)$. The results showed that work-unit residents, mostly composed of low-income residents, travelled substantially less than both those living in commodity housing (typically high-income) and in affordable low-income housing. Shen et al. (2015) further differentiated residents relocated into new housing from those moving into affordable housing (Shen et al., 2015). They studied four types of neighborhoods: work-unit, commodity housing, affordable housing, and relocated housing. Using a GPS-assisted online seven-day activity travel diary, along with an online survey, for 709 respondents in the Shangdi-Qinghe area of Beijing in 2012, they examined the flexibility of activities in terms of location and timing. They found flexibility was sensitive to the built environment for residents in relocated housing but not in work-unit neighborhoods where other constraints may have been key, such as institutions and policies. Finally, Wu et al. (2019) randomly surveyed 2,838 people in 21 Beijing neighborhoods in 2015. Focusing on shopping trips they considered how demographic variables, perceptions, and measured built environment characteristics affected the mode choice. Vehicle ownership was key in mode choice, leading to more driving to shop. Of five neighborhood types they found people in old Worker-Villages and Older Neighborhoods were more likely to walk to shops; the highest percentage of those cycling to shops was in the Historical Neighborhoods.

As new central government policies have promoted hinterland development, more attention has focused on Western Chinese cities (Gao, Ahern, \& Koshland, 2016). This paper contributes a valuable analysis of another city in the hinterland with a specific focus on active transport and neighborhoods.

\section{$2.4 \quad$ Conceptual framework}

Our conceptual framework drew on this prior work. We included in all regressions as independent variables key social and economic factors: age, education, employment, gender, household size, and income. Physical variables included neighborhood type; measures of the 3Ds (floor area ratio, land-use dissimilarity, and intersection density); variables related to cycling and recreation (bike lane availability and riverfront location); and ongoing construction as a constraint on active transport. In addition to the outcome or dependent active transport variables we also examined issues related to mode choice including survey responses about travel time, the number of perceived mode alternatives, and car ownership. Bicycle ownership was not included because bicycles are widely available and not a constraint on mode choice.

\section{$3 \quad$ Methods}

\subsection{Study area}

Chengdu, the capital city of Sichuan Province, is one of the fastest developing cities in western China. Since 2003, Chengdu has been a pioneer in terms of coordinated urban-rural development (Qin, 2015). Between 1949 and 2011, the built-up area in the central city expanded from $18 \mathrm{~km}^{2}$ to $354 \mathrm{~km}^{2}$ (Qin, 2015; CSB, 2017). Chengdu also ranks high on livability and percentage of active transport among Chinese cities (National Resources Defense Council, 2017). This study covered most of Chengdu’s 
urban area within the fourth ring in 2016. At the time there were only three metro lines, focused on the central area, but a wider network of buses.

\subsection{Data collection}

\subsubsection{Sampling}

The Research Center for Contemporary China (RCCC) at Peking University, in collaboration with the Harvard-China Project, conducted the sampling and fieldwork during June and July in 2016. A spatial sampling approach was used. The main Chengdu metropolitan districts (population 3.6 million) were divided into a grid representing half-square minutes (HSMs) of latitude and longitude ( $\mathrm{N}=968$; approximately 923 by 804 meters). From these, 40 neighborhoods, or Primary Sampling Units (PSUs), were randomly sampled: 13 inside and 27 outside the second ring. These 40 areas were in turn divided into 80 one-minute squares of approximately $90^{*} 90$ meters, or Secondary Sampling Units (SSUs). Population densities were calculated using the Chengdu Statistical Yearbook of 2015.

Within each of the 40 PSU neighborhoods one SSU was randomly sampled for interviews, and if it did not have enough residential units a replacement area was selected from four back-up SSUs. Surveyors recorded all addresses and then 30-60 dwellings were sampled. Two surveys were conducted-half of the households answered the travel survey that this paper is based on, and a different half answered a health survey. To protect privacy, the dataset only records the neighborhood and not the secondary sampling unit (Research Center for Contemporary China, 2016).

Individual level data involved in-person surveys conducted by trained interviewers who were local university students. Eligible participants were aged 18-70, of Chinese nationality, and had lived in Chengdu for at least one year in typical residential areas, i.e. not housing areas for military, central ministries, consulates, prisons, tourist/religious sites, and infrastructure buildings. Surveyors collaborated with local neighborhood/village committees and social service organizations in gaining access to residents, and interviewers made multiple attempts to reach respondents. They had some difficulty in very secure buildings. In total, 1,048 valid individual interviews were completed for a response rate of $61 \%$. One person was interviewed per household, and it is their data we use, although they were asked about other members (Research Center for Contemporary China, 2016). The survey was lengthy and included general questions about demographics and travel as well as a recall survey akin to a travel diary for one usual weekday.

GIS data came from multiple online sources including Open Street Map, Esri Open Data, and Google Earth collected in 2017. These data were georeferenced into the WGS84 UTM zone $48 \mathrm{~N}$ for spatial analysis to generate urban form variables. For data consistency, digital globe images in January 2017 were used as backgrounds for all neighborhoods to minimize tree obstructions. Time lapse data were used to identify the presence of areas in shadow. Further, the 80 SSUs were georeferenced and overlaid over the background in each PSU to capture more information from high resolution images ranging from 5 to 15 meters per pixel.

Specific variables were constructed from multiple sources (Table 3). Density was approximated using floor area ratio (FAR) i.e., building area divided by land area, estimated by building footprint times number of stories based on visual observation of satellite images obtained from Google Earth, using the SSU as the base unit for calculation. Dissimilarity was calculated using land-use function diversity adopting the Kaufman and Rousseau (1990) model with six land-use categories: (1) high rise (20+ floors); (2) mid-rise (8-19 floors); and (3) low-rise (up to 7 floors) residential; (4) commercial, office, institutional, and mixed use; (5) park, playgrounds, and open space; and (6) infrastructure/utilities. Land-use data included the Chengdu Master Plan (land use) in ArcGIS, Google Earth, Digital Globe, 
and Baidu maps. Dissimilarity ranged from 0 (high dissimilarity) to 1 (low). While this means that a mix of three residential types would generate a moderate dissimilarity index, higher density residential areas tend to include commercial service uses on the lower floors. Bike lane availability, riverfront location (adjacency), ongoing construction, and number of road intersections were interpreted from Google Earth and Baidu images as well as ground-truth validations. A neighborhood was considered to have a bike lane if such designated lanes were provided for at least half of the road distance. Riverfront location was where at least one third of the housing estates in the neighborhood were adjacent to the riverfront.

Table 3. Variable definitions and rationales

\begin{tabular}{|c|c|c|}
\hline Variable & Measure & Definition and/or reason \\
\hline \multicolumn{3}{|c|}{ Physical characteristics (neighborhood level) } \\
\hline Bike lane availability & Binary & Designated lanes were provided for at least half of the road distance ${ }^{1}$ \\
\hline Construction & Binary & Ongoing construction in at least one $S \mathrm{U}^{1}$; a measure of disruption \\
\hline Dissimilarity & 0 to 1 & $\begin{array}{l}\text { Land use function diversity adopting the Kaufman and Rousseau } \\
\text { (1990) model with six land use categories }{ }^{2} \text {; a proxy for destinations }\end{array}$ \\
\hline Floor Area Ratio & $1,000 \mathrm{~m} 2 / \mathrm{ha}$ & $\begin{array}{l}\text { Floor area ratio (FAR) i.e. building volume over land }(1,000 \mathrm{~m} 2 / \mathrm{ha})^{1} \text {; } \\
\text { proxy for density }\end{array}$ \\
\hline Intersections & Number & $\begin{array}{l}\text { Total number of vehicular intersections in PSU; a measure of route } \\
\text { options }\end{array}$ \\
\hline Riverfront (\% adjacent) & Binary & $\begin{array}{l}\text { At least one third of the housing estates in the neighborhood were } \\
\text { adjacent to the riverfront }{ }^{*}\end{array}$ \\
\hline \multicolumn{3}{|c|}{ Transportation variables (individual level, self-reported from survey) } \\
\hline $\begin{array}{l}\text { Trips - Mode choice NMT } \\
\text { vs. MT for work and non- } \\
\text { work trips }\end{array}$ & $\begin{array}{l}\text { Binary NMT or } \\
\text { MT }\end{array}$ & $\begin{array}{l}\text { Movement between locations assessed via recall survey. Non-motor- } \\
\text { ized trips (NMT) include walking and pedal cycling. Motorized trips } \\
\text { (MT) include private car, car sharing, company car, private van or } \\
\text { truck, motorcycle, and motorized bicycles and tricycles. Transit, also a } \\
\text { motorized mode, includes bus or subway. }{ }^{4}\end{array}$ \\
\hline Work trips & & $\begin{array}{l}\text { Trip purpose is to commute to primary place of work from home or } \\
\text { someplace else or returning home from work }\end{array}$ \\
\hline Non-work trips & & $\begin{array}{l}\text { Trip purpose is not commuting to work or returning home from } \\
\text { work }\end{array}$ \\
\hline Trips—all NMT trips & Number & Number of walk and cycle trips on the usual day \\
\hline Travel time & Minutes & Moving, transfer, and idling time between locations for trip taken \\
\hline Number of mode options & Number & $\begin{array}{l}\text { Number of alternatives other than the reported trip mode, ranging } \\
\text { from } 0 \text { (no alternative) to } 8\end{array}$ \\
\hline Bicycle ownership $^{3}$ & Number & Number of bicycles owned per 100 households \\
\hline Car ownership & Number & Number of private cars owned per 100 households \\
\hline \multicolumn{3}{|c|}{ Respondent characteristics (individual level, self-reported from survey) } \\
\hline Age & Years & Age of respondent \\
\hline Education & Years & Years of education of respondent \\
\hline Employment & Binary & Employed (1) or not $(0)$ \\
\hline Gender & $\%$ women & Percentage of females among respondents \\
\hline Household size & Number & Number of people in a household \\
\hline Income & $\%$ of low income & $\begin{array}{l}\text { Income stratification was based on household income; the low } \\
\text { income cut offs was below 15,000 RMB }\end{array}$ \\
\hline
\end{tabular}

${ }^{1}$ Via visual interpretation of imagery, data sources explained in detail in the text.

2 From multiple data sources, as explained in the text.

${ }^{3}$ Not in the regression because affordable and not considered a limitation on mode choice.

${ }_{4}^{4}$ Walking/cycling trips to and from transit were noted as separate NMT trips in this survey—only the actual transit trip is counted as motorized. 
Other variables came from the survey as described in Table 3. One item is notable. Because walk/ cycle trips to transit were counted separately in this survey, we included transit as a motorized mode.

\subsection{Analysis}

Data were analyzed in Stata statistical software (version 12). ANOVA was used to assess differences among neighborhoods for key variables. Vehicle ownership patterns were studied by controlling income groups due to the high diversity of residents' economic class in Chengdu's urban neighborhoods.

Because non-motorized transport (NMT) can be hard to measure-often not all trips are recalled-two series of regression models were created. To account for the complex sampling pattern, where participants were not simply drawn by a random procedure from the entire population, we applied the Stata command svy to each regression. In the first series of models, the main models reported in this paper, the dependent variable was mode choice, non-motorized vs motorized (including transit), for every trip in a typical working day, including those starting at home and those not. However, the average number of trips per day was 2.3-2.4, depending on the neighborhood type, with most trips starting or ending at home. We ran separate models for work, non-work, and all purposes. For these models we used multiple logistic regressions. To further test the sensitivity of findings to specification of the dependent variable, we ran a parallel set of linear regression models with the dependent variable the number of NMT trips per person, including those with 0 trips, examining all purposes.

We then tested three models for each of the dependent variables, again to assess the sensitivity of the findings to different definitions of neighborhood. Model 1 followed the Pindyck and Rubinfeld (1998) and the Pan et al. (2009) models, which included socio-demographic variables, transportation variables, and neighborhood types. Model 2 added urban form variables. Model 3 tested the categorization of neighborhood types.

Finally, we also ran both two and three-level multilevel models. As we describe in the statistical appendix, we assumed that people from each neigborhood were nested in one of the four neighborhood types. The dependent variable was active travel trips, separately for work and non-work purposes. In the two-level model, we ignored the neighborhood types. In the three-level model, we incorporated neighborhoods as an additional level.

\section{$4 \quad$ Results}

\subsection{Neighborhood differences}

Table 4 presents descriptive statistics for each of the main variables by neighborhood type. Differences can be seen in most variables between neighborhood types with type 1 (mixed use) and type 4 (affordable) often having the extreme values. In terms of transportation variables, mixed use areas had the lowest number of alternative modes (in part explained by the lowest car ownership rates) in spite of having the highest incomes. The income composition in mixed use neighborhoods was higher than other neighborhoods, likely because of the cluster of high-income jobs around the Central Business District (CBD) and the cultural premium paid to central city location. Commodity housing had the longest reported travel times. Work units had the most non-motorized trips and the most bicycles. However, socially there were many similarities with similar middle-aged to older respondents, approximately half women, with roughly similar educational levels. 
Table 4. Descriptive statistics of sample by neighborhood type

\begin{tabular}{|c|c|c|c|c|c|c|c|c|c|c|c|c|}
\hline \multirow{3}{*}{$\begin{array}{l}\text { Number of } \\
\text { neighborhoods } \\
\text { Number of } \\
\text { respondents }\end{array}$} & \multicolumn{3}{|c|}{$\begin{array}{l}\text { Type } 1 \text { Mixed use } \\
6\end{array}$} & \multicolumn{3}{|c|}{$\begin{array}{l}\text { Type } 2 \text { Work unit } \\
8\end{array}$} & \multicolumn{3}{|c|}{$\begin{array}{l}\text { Type } 3 \text { Commodity } \\
15\end{array}$} & \multicolumn{3}{|c|}{$\begin{array}{l}\text { Type } 4 \text { Affordable } \\
11\end{array}$} \\
\hline & \multicolumn{2}{|l|}{177} & \multicolumn{4}{|c|}{185} & \multicolumn{2}{|l|}{396} & \multicolumn{4}{|c|}{290} \\
\hline & Mean & $\begin{array}{r}\text { Lower } \\
1\end{array}$ & ${ }_{2}$ Upper & Mean & $\begin{array}{r}\text { Lower } \\
1\end{array}$ & ${ }_{2}$ Upper & Mean & $\begin{array}{r}\text { Lower } \\
1\end{array}$ & $\begin{array}{r}\text { Upper } \\
2\end{array}$ & Mean & Lower ${ }^{1}$ & Upper \\
\hline \multicolumn{13}{|c|}{ Physical Characteristics (neighborhood level) } \\
\hline $\begin{array}{l}\text { Bike lane } \\
\text { availability }^{2}\end{array}$ & $85.7 \%$ & - & - & $50.0 \%$ & - & - & $60.0 \%$ & - & - & $7.7 \%$ & - & - \\
\hline Construction & $14.3 \%$ & - & - & $40.0 \%$ & - & - & $50.0 \%$ & - & - & $76.9 \%$ & - & - \\
\hline Dissimilarity & 0.2 & 0.2 & 0.3 & 0.3 & 0.1 & 0.3 & 0.2 & 0.1 & 0.3 & 0.2 & 0 & 0.3 \\
\hline $\begin{array}{l}\text { FAR } \\
(1,000 \mathrm{~m} 2 / \mathrm{ha})\end{array}$ & 8.2 & 5.7 & 10.9 & 6.8 & 5 & 8.3 & 8.5 & 5.9 & 10.6 & 4.1 & 0.9 & 7.6 \\
\hline Intersections & 16.9 & 12 & 21 & 15.8 & 9 & 23 & 16.3 & 11 & 22 & 12.8 & 5 & 21 \\
\hline Riverfront $^{1}$ & $85.7 \%$ & - & - & $20.0 \%$ & - & - & $10.0 \%$ & - & - & $23.1 \%$ & - & - \\
\hline \multicolumn{13}{|c|}{ Transportation variables (individual level) } \\
\hline $\begin{array}{l}\text { Travel time } \\
\text { (minutes) }\end{array}$ & 18.1 & 15 & 23.7 & 18.6 & 13.2 & 28.7 & 23.2 & 17.2 & 30 & 19.4 & 12.5 & 23.1 \\
\hline $\begin{array}{l}\text { Number of } \\
\text { mode options }\end{array}$ & 0.8 & 0.6 & 1.2 & 0.9 & 0.2 & 1.9 & 1.2 & 0.5 & 2.1 & 1.2 & 0.5 & 1.5 \\
\hline \multicolumn{13}{|c|}{ Survey respondent characteristics (individual level) } \\
\hline Age (years) & 41.8 & 35.5 & 55 & 42 & 35.9 & 46.4 & 41.5 & 32.8 & 53.5 & 44.1 & 36.1 & 58.8 \\
\hline $\begin{array}{l}\text { Education } \\
\text { (years) }\end{array}$ & 10.3 & 9 & 11.5 & 10.1 & 7.7 & 13 & 10 & 7.9 & 14.7 & 9.5 & 6.1 & 11.8 \\
\hline $\begin{array}{l}\text { Employment } \\
\text { (\% employed) }\end{array}$ & $70.9 \%$ & & & $65.2 \%$ & & & $59.6 \%$ & & & $64.6 \%$ & & \\
\hline $\begin{array}{l}\text { Gender }(\% \\
\text { women })\end{array}$ & $48.6 \%$ & $35.0 \%$ & $53.6 \%$ & $55.6 \%$ & $46.4 \%$ & $64.9 \%$ & $50.0 \%$ & $40.9 \%$ & $58.8 \%$ & $49.2 \%$ & $39.1 \%$ & $53.8 \%$ \\
\hline Household size & 2.1 & 1 & 6 & 2.4 & 1 & 6 & 2.3 & 1 & 14 & 2.4 & 1 & 7 \\
\hline $\begin{array}{l}\text { Income (\% of } \\
\text { low) }\end{array}$ & $5.7 \%$ & $0.0 \%$ & $8.7 \%$ & $9.6 \%$ & $0.0 \%$ & $30.8 \%$ & $11.2 \%$ & $0.0 \%$ & $25.0 \%$ & $14.7 \%$ & $0.0 \%$ & $34.8 \%$ \\
\hline
\end{tabular}

${ }^{1}$ Lower neighborhood value for neighborhood level variables and neighborhood average for individual level variables.

${ }^{2}$ Upper neighborhood value for neighborhood level variables and neighborhood average for individual level variables.

To demonstrate the variations among the four neighborhood types, we ran ANOVA tests on the individual level and physical neighborhood variables in Table 4, separately for work and non-work trips by neighborhood. There were statistically significant differences by neighborhood type in all variables except for gender, age, household size, and employment status. Urban form variables all demonstrated large r-squared values indicating substantial differences by neighborhood type, particularly for FAR. The variation in travel time, number of mode options, income, and car ownership was not explained much by differences in neighborhood type, even though the differences are statistically significant. 
Table 5 presents data for the travel modes demonstrating some variation across neighborhood types, particularly for mixed use compared with commodity housing and work units for work/non-work split and work unit and affordable compared with the others for non-motorized trips. Non-motorized modes are more likely to be used for non-work trips than for work trips in all neighborhood types.

Table 5. Individual level travel mode split by neighborhood type

\begin{tabular}{|c|c|c|c|c|c|c|c|c|}
\hline & \multicolumn{2}{|c|}{ Type 1 Mixed use } & \multicolumn{2}{|c|}{ Type 2 Work unit } & \multicolumn{2}{|c|}{ Type 3 Commodity } & \multicolumn{2}{|c|}{ Type 4 Affordable } \\
\hline $\begin{array}{l}\text { Number of neighbor- } \\
\text { hoods }\end{array}$ & 6 & & 8 & & 15 & & 11 & \\
\hline \multirow[t]{2}{*}{ Number of respondents } & 177 & & 185 & & 396 & & 290 & \\
\hline & Number & $\%$ Total & Number & $\%$ Total & Number & \% Total & Number & $\%$ Total \\
\hline \multicolumn{9}{|c|}{ Transportation variables (individual level) } \\
\hline All trips & 406 & $100 \%$ & 451 & $100 \%$ & 940 & $100 \%$ & 670 & $100 \%$ \\
\hline Non-motorized trips & 258 & $64 \%$ & 327 & $73 \%$ & 600 & $64 \%$ & 475 & $71 \%$ \\
\hline Motorized trips & 148 & $36 \%$ & 124 & $27 \%$ & 340 & $36 \%$ & 195 & $29 \%$ \\
\hline Work trips & 226 & $56 \%$ & 214 & $47 \%$ & 436 & $46 \%$ & 342 & $51 \%$ \\
\hline Non-motorized trips & 121 & $30 \%$ & 135 & $30 \%$ & 201 & $21 \%$ & 207 & $31 \%$ \\
\hline Motorized trips & 105 & $26 \%$ & 79 & $18 \%$ & 235 & $25 \%$ & 135 & $20 \%$ \\
\hline Non-work trips & 180 & $44 \%$ & 237 & $53 \%$ & 504 & $54 \%$ & 328 & $49 \%$ \\
\hline Non-motorized trips & 137 & $34 \%$ & 192 & $43 \%$ & 399 & $42 \%$ & 268 & $40 \%$ \\
\hline Motorized trips & 43 & $11 \%$ & 45 & $10 \%$ & 105 & $11 \%$ & 60 & $9 \%$ \\
\hline Trips per person & 2.29 & & 2.44 & & 2.37 & & 2.31 & \\
\hline Work trips pp & 1.28 & & 1.16 & & 1.10 & & 1.18 & \\
\hline Non-work trips pp & 1.02 & & 1.28 & & 1.27 & & 1.13 & \\
\hline
\end{tabular}

Vehicle ownership is a key factor in mode decisions. Table 6 describes vehicle ownership by low, middle, and high-income categories. High-income groups in all neighborhood types had higher rates of car ownership. Rates were lowest in the commodity neighborhoods (56.8\%) and highest in the work-unit neighborhoods (72.7\%). The results show that in work-unit neighborhoods only low-income groups take advantage of the jobs/housing balance, and even then more own cars than in mixed use areas, with other income groups having similar or higher rates of car ownership to other neighborhood types. Commodity housing had the smallest gaps of car ownership percentage among income groups. In affordable housing, both high- and low-income groups own relatively high percentages of cars and bicycles. 
Table 6. Vehicle ownership by neighborhood type and income

\begin{tabular}{|c|c|c|c|c|c|}
\hline & & Mixed use & Work-unit & Commodity & Affordable \\
\hline \multicolumn{6}{|l|}{ Low income ${ }^{1}$} \\
\hline No. of Response & & 12 & 21 & 44 & 22 \\
\hline Bicycle2 & $\%$ own & $50.0 \%$ & $14.3 \%$ & $38.6 \%$ & $63.6 \%$ \\
\hline Car2 & $\%$ own & $0.0 \%$ & $4.8 \%$ & $13.6 \%$ & $9.1 \%$ \\
\hline Middle income $^{1}$ & & 129 & 108 & 252 & 196 \\
\hline \multicolumn{6}{|l|}{ No. of Response } \\
\hline Bicycle & $\%$ own & $42.6 \%$ & $49.1 \%$ & $48.0 \%$ & $46.4 \%$ \\
\hline Car & $\%$ own & $13.2 \%$ & $19.4 \%$ & $22.6 \%$ & $14.3 \%$ \\
\hline High income $^{1}$ & & 36 & 55 & 95 & 66 \\
\hline \multicolumn{6}{|l|}{ No. of Response } \\
\hline Bicycle & $\%$ own & $25.0 \%$ & $27.3 \%$ & $49.5 \%$ & $53.0 \%$ \\
\hline Car & $\%$ own & $66.7 \%$ & $72.7 \%$ & $56.8 \%$ & $69.7 \%$ \\
\hline Bicycle ownership & Per 100 household & 49.7 & 42.7 & 60.9 & 57.2 \\
\hline Car ownership & Per 100 household & 25.4 & 35.1 & 32.6 & 28.3 \\
\hline No answer & & 0 & 1 & 5 & 6 \\
\hline
\end{tabular}

${ }^{1}$ Income stratification is based on household. The household income cut-offs are below 15,000 RMB for low income and above 70,000 RMB for high income. Compared with nationwide prefecture-level cities, Chengdu’s per capita GDP 77,000 $\mathrm{RMB}$ in 2016 ranked number two.

${ }^{2}$ Households were asked for the number of vehicles. We have collapsed here into \% who own 1 or more.

\subsection{Regression analyses}

Separate multiple logistic regression models were estimated for work trips and non-work trips. The dependent variable was the likelihood of taking a non-motorized mode vs. a motorized one for every trip taken (see Model 1 in Table 7). It is necessary to separate trips by purpose because mode choice decisions tend to vary by purpose (Ben-Akiva $\&$ Lerman, 1985). Neighborhood type was treated as a factor variable. The reference case was the mixed use traditional neighborhood. 
Table 7. Model 1-The odds of choosing active transport over motorized modes by neighborhood type

\begin{tabular}{|c|c|c|c|c|c|c|}
\hline & Odds Ratio & Coef. & Std. Err. & $\mathbf{t}$ & $P>|t|$ & \\
\hline \multicolumn{7}{|l|}{ Work trips $(n=1,182)$} \\
\hline Travel time & 0.95 & -0.052 & 0.01 & -5.24 & $\mathbf{0}$ & $* * *$ \\
\hline Number of mode options & 1.316 & 0.275 & 0.192 & 1.43 & 0.16 & \\
\hline Female & 1.709 & 0.536 & 0.262 & 2.04 & 0.048 & * \\
\hline Age & 1.046 & 0.045 & 0.012 & 3.67 & 0.001 & ** \\
\hline Education & 0.946 & -0.056 & 0.029 & -1.89 & 0.067 & \\
\hline Employment & 0.958 & -0.043 & 1.235 & -0.03 & 0.972 & \\
\hline Household size & 1.323 & 0.28 & 0.079 & 3.53 & 0.001 & ** \\
\hline Car ownership & 0.279 & -1.276 & 0.22 & -5.79 & $\mathbf{0}$ & $* * *$ \\
\hline Income & 1.005 & 0.005 & 0.005 & 0.94 & 0.355 & \\
\hline \multicolumn{7}{|c|}{ Type (mixed use as the reference case) } \\
\hline Work unit & 2.02 & 0.703 & 0.41 & 1.72 & 0.094 & \\
\hline Commodity & 0.897 & -0.108 & 0.429 & -0.25 & 0.802 & \\
\hline Affordable & 1.484 & 0.395 & 0.384 & 1.03 & 0.311 & \\
\hline Constant & 0.49 & -0.714 & 1.571 & -0.45 & 0.652 & \\
\hline \multicolumn{7}{|l|}{ Non-Work $(\mathrm{n}=1,215)$} \\
\hline Travel time & 0.945 & -0.056 & 0.011 & -5 & $\mathbf{0}$ & $* * *$ \\
\hline Number of mode options & 0.825 & -0.192 & 0.188 & -1.02 & 0.313 & \\
\hline Female & 1.083 & 0.08 & 0.349 & 0.23 & 0.821 & \\
\hline Age & 1.071 & 0.069 & 0.013 & 5.46 & $\mathbf{0}$ & $* * *$ \\
\hline Education & 0.961 & -0.039 & 0.04 & -0.99 & 0.33 & \\
\hline Employment & 0.233 & -1.457 & 0.31 & -4.69 & $\mathbf{0}$ & $* * *$ \\
\hline Household size & 0.841 & -0.174 & 0.135 & -1.29 & 0.205 & \\
\hline Car ownership & 0.452 & -0.795 & 0.299 & -2.65 & 0.012 & * \\
\hline Income & 1.023 & 0.022 & 0.009 & 2.56 & 0.014 & * \\
\hline \multicolumn{7}{|c|}{ Type (mixed use as the reference case) } \\
\hline Work unit & 1.784 & 0.579 & 0.36 & 1.61 & 0.116 & \\
\hline Commodity & 1.23 & 0.207 & 0.364 & 0.57 & 0.574 & \\
\hline Affordable & 0.882 & -0.125 & 0.356 & -0.35 & 0.726 & \\
\hline Constant & 1.951 & 0.668 & 0.788 & 0.85 & 0.402 & \\
\hline
\end{tabular}

Note: Model 1 adopted the framework of the Pan et al. (2009) model, which is derived from the Ben-Akiva and Lerman (1985) model. Type or neighborhood type is a categorical variable, each neighborhood type is assigned a numerical value, e.g., 1 =traditional mixed use; $2=$ work-unit; $3=$ commodity housing; $4=$ affordable

* Significant at 0.05 level, ${ }^{* *}$ significant at 0.01 level, ${ }^{* * *}$ significant at 0.001 level 
Examining the central question in this study, statistically significant results for both work and non-work trips were found for travel time, age, and car ownership. As travel time of the trip taken and car ownership increased, so did motorized modes. The odds ratio for travel time was 0.950 and 0.945 for work trips and non-work trips: for every one minute increase of travel time the odds of using active transport was 5\% lower for work trips and 5.5\% lower for non-work trips that is shorter trips timewise and more active modes. The odds ratio for car ownership was 0.279 and 0.452 for work trips and non-work trips, respectively; owning a car meant an increased likelihood of choosing motorized modes, being $72.1 \%$ more likely for work trips and $54.8 \%$ for non-work trips. The reverse was true for age; being one year older was associated with a 4.6\% (work) and 7.1\% (non-work) increase in the chance of choosing an active mode. Household size and gender were both significant for work trips; females were $70.9 \%$ more likely to choose motorized modes. For non-work trips, as income increased, so did vehicular mode choice; an increase in annual income of 10,000 Yuan (\$US 1,437 in 2016) was associated with a $2.3 \%$ increase in the odds of using a motorized mode; people who had a job were $54.8 \%$ less likely to choose non-motorized modes.

Model 1 used the traditional mixed use neighborhood as the reference case. For both work and non-work trips, no types were significantly different. In the model run for all trips (not shown), overall results were largely the same but neighborhood type was significant for work unit at the 0.05 level.

We added neighborhood-level variables to the logistic regression in Model 2 (Table 8). These neighborhood-level variables were physical features. 
Table 8. Model 2-The odds of choosing active transport over motorized modes by neighborhood type and physical environment variables

\begin{tabular}{|c|c|c|c|c|c|c|}
\hline II1:O17 & Odds Ratio & Coef. & Std. Err. & $\mathbf{t}$ & $P>|t|$ & \\
\hline \multicolumn{7}{|l|}{ Work trips $(n=1,182)$} \\
\hline Travel time & 0.949 & -0.052 & 0.009 & -5.64 & $\mathbf{0}$ & $* * *$ \\
\hline Number of mode options & 1.273 & 0.241 & 0.193 & 1.25 & 0.219 & \\
\hline Female & 1.707 & 0.535 & 0.263 & 2.04 & 0.049 & * \\
\hline Age & 1.044 & 0.043 & 0.013 & 3.4 & 0.002 & ** \\
\hline Education & 0.930 & -0.073 & 0.032 & -2.27 & 0.029 & * \\
\hline Employment & 1.179 & 0.165 & 1.162 & 0.14 & 0.888 & \\
\hline Household size & 1.327 & 0.283 & 0.086 & 3.27 & 0.002 & ** \\
\hline Car ownership & 0.289 & -1.242 & 0.239 & -5.2 & $\mathbf{0}$ & *** \\
\hline Income & 1.001 & 0.001 & 0.006 & 0.12 & 0.907 & \\
\hline FAR & 0.867 & -0.142 & 0.082 & -1.75 & 0.089 & \\
\hline Dissimilarity & 13.838 & 2.627 & 1.760 & 1.49 & 0.144 & \\
\hline Intersection & 1.010 & 0.009 & 0.020 & 0.48 & 0.633 & \\
\hline Bike lane & 1.804 & 0.590 & 0.444 & 1.33 & 0.192 & \\
\hline Riverfront & 1.275 & 0.243 & 0.277 & 0.88 & 0.385 & \\
\hline Construction & 0.643 & -0.442 & 0.308 & -1.44 & 0.159 & \\
\hline \multicolumn{7}{|c|}{ Type (mixed use as the reference case) } \\
\hline Work unit & 2.467 & 0.903 & 0.458 & 1.97 & 0.05 & * \\
\hline Commodity & 2.108 & 0.746 & 0.477 & 1.56 & 0.126 & \\
\hline Affordable & 2.680 & 0.986 & 0.584 & 1.69 & 0.100 & \\
\hline constant & 0.541 & -0.614 & 1.79 & -0.34 & 0.734 & \\
\hline \multicolumn{7}{|l|}{ Non-Work $(n=1,215)$} \\
\hline Travel time & 0.949 & -0.052 & 0.011 & -4.78 & $\mathbf{0}$ & $* * *$ \\
\hline Number of mode options & 0.863 & -0.148 & 0.212 & -0.7 & 0.490 & \\
\hline Female & 1.019 & 0.019 & 0.351 & 0.05 & 0.957 & \\
\hline Age & 1.068 & 0.065 & 0.012 & 5.35 & $\mathbf{0}$ & $* * *$ \\
\hline Education & 0.949 & -0.053 & 0.040 & -1.34 & 0.189 & \\
\hline Employment & 0.214 & -1.540 & 0.335 & -4.6 & $\mathbf{0}$ & $* * *$ \\
\hline Household size & 0.844 & -0.170 & 0.146 & -1.16 & 0.253 & \\
\hline Car ownership & 0.459 & -0.778 & 0.320 & -2.43 & 0.02 & * \\
\hline Income & 1.014 & 0.014 & 0.008 & 1.63 & 0.112 & \\
\hline FAR & 0.803 & -0.220 & 0.070 & -3.13 & 0.003 & ** \\
\hline Dissimilarity & 0.092 & -2.386 & 1.719 & -1.39 & 0.173 & \\
\hline Intersection & 1.030 & 0.030 & 0.020 & 1.44 & 0.158 & \\
\hline Bike lane & 0.787 & -0.239 & 0.307 & -0.78 & 0.441 & \\
\hline Riverfront & 0.909 & -0.095 & 0.320 & -0.3 & 0.768 & \\
\hline Construction & 0.840 & -0.174 & 0.334 & -0.52 & 0.605 & \\
\hline \multicolumn{7}{|c|}{ Type (mixed use as the reference case) } \\
\hline Work unit & 1.377 & 0.320 & 0.441 & 0.73 & 0.472 & \\
\hline Commodity & 0.867 & -0.142 & 0.377 & -0.38 & 0.708 & \\
\hline Affordable & 0.27 & -1.309 & 0.546 & -2.4 & 0.022 & * \\
\hline constant & 31.844 & 3.461 & 1.203 & 2.88 & 0.007 & \\
\hline
\end{tabular}

* Significant at 0.05 level, ${ }^{* *}$ significant at 0.01 level, ${ }^{* * *}$ significant at 0.001 level 
The variables significant in Model 1 largely remained significant in Model 2. Some additional variables attained significance. For work trips more education led to less active transport. For work trips, the work unit was statistically significant at the 0.05 level with those residing in such units more than twice as likely to take non-motorized work trips compared with the reference case (mixed use) after controlling for other variables. For non-work trips, FAR was negatively related to active transport; that is, areas with more buildings had less active transport. Those in affordable housing were less likely to use active transport for non-work trips than those in mixed use areas. The explanation could be related to the distant location of such areas relative to social activities and the suburbanization of employment.

To validate the categorization of neighborhood types in Model 2, we introduced an additional Model 3, with a different categorization of neighborhoods. Model 3 defined each of the 40 neighborhoods as its own type. As shown in Table 9, among the socio-economic variables, those significant in Model 2 remained so, with the exception of gender for work trips. Additional urban form variables achieved significance. Ongoing construction was significant for both work and non-work trips but with different directions: increasing non-motorized work trips and decreasing non-work trips. For work trips, the odds of choosing active modes was higher for areas with high land-use dissimilarity and riverfront locations and the lower in areas with greater numbers of intersections. The large odds ratio for dissimilarity is an artifact of not normalizing the index. The intersection finding may reflect the pattern of off-street walkways in Chinese developments so pedestrians do not necessarily use streets for walking and have other, unmeasured, options. For non-work trips, more active transport occurred in areas with more bike lanes with a high magnitude of 10.022, meaning the presence of bike lanes can increase the likelihood of choosing active trip by more than 10 -fold. 
Table 9. Model 3-The odds of choosing active transport over motorized mode at the individual neighborhood level

\begin{tabular}{|c|c|c|c|c|c|c|}
\hline & Odds Ratio & Coef. & Std. Err. & $\mathbf{t}$ & $P>|t|$ & \\
\hline \multicolumn{7}{|l|}{ Work trips $(n=1,182)$} \\
\hline Travel time & 0.942 & -0.059 & 0.01 & -5.84 & $\mathbf{0}$ & $* * *$ \\
\hline Number of mode options & 1.304 & 0.266 & 0.223 & 1.19 & 0.24 & \\
\hline Female & 1.67 & 0.513 & 0.283 & 1.81 & 0.078 & \\
\hline Age & 1.052 & 0.05 & 0.016 & 3.24 & 0.003 & ** \\
\hline Education & 0.922 & -0.081 & 0.039 & -2.08 & 0.045 & * \\
\hline Employment & 2.913 & 1.069 & 1.084 & 0.99 & 0.33 & \\
\hline Household size & 1.452 & 0.373 & 0.091 & 4.09 & $\mathbf{0}$ & $* * *$ \\
\hline Car ownership & 0.239 & -1.43 & 0.271 & -5.28 & $\mathbf{0}$ & $* * *$ \\
\hline Income & 0.997 & -0.003 & 0.01 & -0.25 & 0.804 & \\
\hline Density & 1.067 & 0.065 & 0.064 & 1 & 0.322 & \\
\hline Dissimilarity & 566.417 & 6.339 & 1.948 & 3.25 & 0.002 & $* *$ \\
\hline Intersection & 0.934 & -0.068 & 0.009 & -7.22 & $\mathbf{0}$ & $* * *$ \\
\hline Bike lane & 0.985 & -0.015 & 0.228 & -0.06 & 0.949 & \\
\hline Riverfront & 4.457 & 1.494 & 0.688 & 2.17 & 0.036 & * \\
\hline Construction & 7.006 & 1.947 & 0.354 & 5.5 & $\mathbf{0}$ & $* * *$ \\
\hline constant & 0.012 & -4.446 & 1.332 & -3.34 & 0.002 & \\
\hline \multicolumn{7}{|l|}{ Non-Work $(\mathrm{n}=1,215)$} \\
\hline Travel time & 0.944 & -0.058 & 0.014 & -4.18 & $\mathbf{0}$ & $* * *$ \\
\hline Number of mode options & 0.864 & -0.146 & 0.302 & -0.48 & 0.631 & \\
\hline Female & 1.087 & 0.084 & 0.414 & 0.2 & 0.841 & \\
\hline Age & 1.064 & 0.062 & 0.015 & 4.01 & $\mathbf{0}$ & $* * *$ \\
\hline Education & 0.936 & -0.066 & 0.044 & -1.49 & 0.145 & \\
\hline Employment & 0.165 & -1.803 & 0.408 & -4.42 & $\mathbf{0}$ & $* * *$ \\
\hline Household size & 0.831 & -0.186 & 0.175 & -1.06 & 0.297 & \\
\hline Car ownership & 0.283 & -1.264 & 0.491 & -2.57 & 0.015 & * \\
\hline Income & 0.944 & -0.058 & 0.042 & -1.38 & 0.177 & \\
\hline Density & 1.478 & 0.391 & 0.289 & 1.35 & 0.185 & \\
\hline Dissimilarity & 0.885 & -0.123 & 0.898 & -0.14 & 0.892 & \\
\hline Intersection & 1.075 & 0.072 & 0.048 & 1.5 & 0.144 & \\
\hline Bike lane & 10.022 & 2.305 & 0.576 & 4 & $\mathbf{0}$ & $* * *$ \\
\hline Riverfront & 3.426 & 1.232 & 1.377 & 0.89 & 0.377 & \\
\hline Construction & 0.043 & -3.153 & 0.602 & -5.23 & $\mathbf{0}$ & $* * *$ \\
\hline constant & 61.713 & 4.123 & 1.066 & 3.87 & 0 & \\
\hline
\end{tabular}

Note: For work trips, individual PSUs with significant p-value included 4 mixed use, 4 work-unit, 6 commodity, and 5 affordable neighborhoods. The respective numbers for non-work trips are 5, 4,4, and 3 .

At the individual neighborhood level, the variation of NMT activity is high. Using a work-unit neighborhood as the baseline, 19 out of 39 PSUs had significantly different choices of active transport modes for work trips and 16 out of 39 for non-work trips. For work trips, the high coefficients of workunit type of neighborhoods indicate variation within the type is also high. For non-work trips, all but 
affordable housing neighborhoods have negative coefficients, meaning the variation within the affordable housing is also high.

To further assess these models, we ran additional linear regression models with the dependent variable the number of non-motorized trips per person, rather than the likelihood of taking a nonmotorized trip. These had largely the same results. In model 1A, with mixed use as the reference case, those in work units were significantly likely to take non-motorized transportation, a similar pattern to the logistic regression, though in this case it achieved significance. In Model 2A; no neighborhood types were significant although work units were on the margin $(\mathrm{p}=0.067)$. Model $3 \mathrm{~A}$ shows that when all trips were considered, all physical environment variables were statistically significant akin to logistic regression models, as were most individual neighborhoods. However, the direction of association with urban form variables was not always the same. Differences included construction and riverfront (negative). Income was added to the significant social variables. For each model the R-squared improved over the main models $(0.39,0.40,0.44)$. Overall models were fairly similar, although neighborhood types were somewhat less significant in the linear regressions.

Finally, we conducted multilevel modeling analysis (see Appendix) and the results show that the multilevel approach was largely similar though, compared to Model 2, FAR achieved significance for work trips where more FAR led to less non-motorized travel. Compared to Model 3, both FAR and gender achieved significance for work trips. In terms of recognizing hierarchical clusters and considering both fixed and random effects, the multilevel model performed better than the other models for work trips $(\mathrm{P}=0.001)$ but not for non-work trips. For example, the multilevel model was able to capture the gender differences for non-work trips at the 0.01 significant level (females were more likely to choose active travel than male) that were either not captured (in Model 3) or only significant at the 0.05 level (in Model 2). In other words, the multilevel model was able to amplify some of the findings from Model 3 but largely in consistent with identifying which variables affecting active travel. We conclude that for work trips, there were hierarchical relationships between neighborhood types and people's travel behaviors.

\section{Discussion}

Urban form variables at the neighborhood scale changed the result of regression models in relation to active transport, though with complex patterns. Similarly, neighborhood type had some association with active transport but perhaps less than might seem likely given differences among neighborhoods in terms of their histories, urban forms, and demographics.

In Model 1 when only socio-economic variables were included, neither work trips nor non-work trips were significantly associated with neighborhood types. In Model 2, which included urban form variables as well as the four categories of neighborhoods, work-unit type of neighborhoods had significantly more active transport to work and affordable housing had significantly less active transport for non-work purposes. This clearly demonstrates how research in a wide variety of cultural, social, and built environment contexts can add nuance to contemporary understanding of associations between built environments and active transport.

We speculate that the work units still benefited from some of the proximity between work places and housing that had been more common in the pre-reform period, making walking or cycling to work more common in this type. In contrast affordable housing is often located in more peripheral areas making driving or taking motorized public transit more likely. One explanation is that there were not enough amenities within walking or biking distance. A second explanation is that placing transit in motorized modes may have affected our findings as people were using transit for non-work trips. Further, of non-work trips, the raw number of motorized trips per person was the second lowest of neighborhood 
types, behind only those in the mixed-use areas (Table 5). Thus while given social and physical features of the neighborhood one might expect fewer motorized trips, the numbers were not large.

\section{Conclusion}

This paper contributes a refined typology of Chinese neighborhoods and assesses its relevance for understanding active transport. Using multiple models and different outcome variables we investigated the robustness of associations between neighborhood type and non-motorized transportation in a noncoastal Chinese city. Generally, people in work unit, slab block types of neighborhoods had greater odds of using active modes of transportation for work trips. Those in affordable housing had the lowest odds of using non-motorized, active transportation modes for non-work trips.

Of the 3-D physical environment variables, FAR (density) was only significant in Model 2 for non-work trips, with more density leading to less active transport. Intersection density and dissimilarity (land-use diversity) were only significant in Model 3 for work trips, with more diversity leading to more active transport.

These findings show that social, built environment, and neighborhoods do matter but in ways that reflect their cultural and urban contexts. Some of the findings mirror those found in prior studies which have generally not looked at the Chinese hinterland. But many variables we assumed would be significant were not, such as some of the " $\mathrm{D}$ " variables, perhaps reflecting the specifics of Chinese urban form. Our carefully constructed neighborhood typology did show some associations with active transport, but the patterns were subtle and less dramatic than we had imagined given their differences on the ground. Going forward theory needs to grapple with place-specific findings from a wider range of contexts. This empirical study of a city in the Chinese hinterland contributes to enlarging this evidence base.

Some factors related to the specifics of this study provide limitations. Because of the difficulties of getting accurate population figures in the newest areas, we used estimates of FAR as a proxy for population density. This may not have been a good enough proxy. In many larger Chinese cities, FAR does not exhibit a gradient pattern as in many U.S. and European cities, where it flattens out from the center city to almost the edge of the city. In many countries, high FAR is associated with general accessibility to downtown destinations as well as historic character or highly designed environments. In larger cities in China the situation is different, as high FAR locations occur throughout the metropolitan area-in well-serviced core and suburban areas and also in places far from work, services, and transit.

Something similar might be said about dissimilarity in that the character of mix in China may not represent the kind of land uses that promote active transport. Alternatively, in high FAR areas where shops and other services are widely available, all residential areas likely have some sort of mixture of uses. This means that there are few purely residential areas, making dissimilarly less useful as a measure in larger Chinese cities. In Chinese superblocks, street intersection density may not reflect pedestrian path networks and route options. In China's smaller towns, FAR, dissimilarity, and intersection density may well matter but this is a topic for more research. Overall, more investigation is needed into the 3-Ds and 6-Ds in a variety of urban contexts.

In terms of the neighborhood classification, while types were different there may have been some mixing of types within particular areas. Data were generally from 2016 (the survey) and 2017 (geospatial data), and we examined earlier data to assess stability, but in China's fast-growing context some environments may have changed in significant ways in one year. As many people live only part of their day and week in residential neighborhoods, the lack of information about other environments (e.g. work, recreational) is also a limitation.

We used an existing survey which had strengths and weaknesses. It was designed to pay attention 
to spatial dimensions but did not include objective data on neighborhoods-we had to construct that data set. For reasons of privacy, the data set did not include the specific location within the 900 by 720 meters neighborhoods (PSUs) where respondents lived. Respondents were clustered within a single area of approximately 90 by 90 meters (an SSU) but we do not know where within the neighborhood that was. People in very secure buildings from work unit or commodity housing were more difficult to reach and it may well be the same for people without residency (Hukou). It was also a long survey and while the response rate was $61 \%$, there may have been fatigue in answering the questions. The travel data was based on recall, and was for one weekday only and included trips that started in a variety of locations, not just the neighborhood. Only a low percentage of walk to transit trips were recorded, likely undercounting walk trips to transit.

This study shows that looking at different physical and cultural contexts can provide important information for testing conceptual frameworks developed in a narrow range of countries and cities. In addition, performing sensitivity analyses can help determine the robustness of associations. In this light, further research in China but outside the major coastal cities would help build knowledge about associations between built environments and active transport. This will help provide a more substantial base of research for evidence-informed policy-making.

\section{Acknowledgements}

This research is sponsored by the Shanghai Pujiang Program, Grant No. 2019PJC076; Key Program of the National Natural Science Foundation of China, Grant No. 7183000103; the PEAK Urban programme of University of Oxford, Grant Ref: ES/P01105 5/1. The Chengdu household survey was conducted by the Harvard-China Project on Energy Economy and Environment of the Harvard John A. Paulson School for Engineering and Applied Sciences, Harvard University, and the Research Center for Contemporary China of Peking University. We are grateful for the support of the Harvard Global Institute, under an award on the theme of "China 2030/2050: Energy and Environmental Challenges for the Future."

\section{Appendix}

Appendix availabe at https:/www.jtlu.org/index.php/jtlu/article/view/1697 


\section{References}

Baranowski, T., Cullen., K, Micklas, T., Thompson, D., and Baranowski, J. (2003). Are current health behavioral change models helpful in guiding prevention of weight gain efforts. Obesity Research, 11, 23-43.

Ben-Akiva, M., and Lerman, S. (1985). Discrete choice analysis. Cambridge, MA: MIT Press.

Boussauw, K., and Witlox, F. (2011). Linking expected mobility production to sustainable residential location planning: some evidence from Flanders. Journal of Transport Geography, 19 (4) 936-942.

Cerin, E., Nathan, A., van Cauwenberg, J., Barnett, D.W., \& Barnett, A. (2017). The neighborhood physical environment and active travel in older adults: A systematic review and meta-analysis. International Journal of Behavioral Nutrition and Physical Activity, 14, 15-38.

Cervero, R. (2013). Linking urban transport and land use in developing countries. Journal of Transport and Land Use, 6, 7-24.

Cervero, R., and Kockelman, K. (1997). Travel demand and the 3Ds: Density, diversity, and design. Transportation Research Part D: Transport and Environment, 2(3), 199-219.

Chengdu Statistics Bureau (CSB). (2017). Chengdu statistics yearbook, 2016. Chengdu: Chengdu Statistics Press.

China Sustainable Transportation Center (2012). China urban non-motorized transport system planning and design guideline. http://www.chinastc.org/en/project/50/397

Day, K. (2016). Built environmental correlates of physical activity in China: A review. Preventive Medicine Reports, 3, 303-316.

D’Haese, S., Vanwolleghem, G., Hinckson, E., De Bourdeaudhuij, I., Deforche, B., Van Dyck, D., \& Cardon, G. (2015). Cross-continental comparison of the association between the physical environment and active transportation in children: A systematic review. International Journal of Behavioral Nutrition and Physical Activity, 12, 145-157.

Ewing, R., \& Cervero, R. (2010). Travel and the built environment: a meta-analysis. Journal of American Planning Association, 76(3), 265-294.

Feng, J., Dijst, M., Wissink, B., \& Prillwitz, J. (2014). Understanding mode choice in the Chinese context: The case of Nanjing metropolitan area. Tijdschrift Voor Economische En Sociale Geografie, 105(3), 315-330.

Forsyth, A., \& Crewe, K. (2009). A typology of comprehensive designed communities since the second world war. Landscape Journal, 28(1), 56-78.

Forsyth, A., \& Krizek, K. (2010). Promoting walking and bicycling: Assessing the evidence to assist planners. Built Environment, 36(4), 429-446.

Gao, M., Ahern, J., \& Koshland, C. P. (2016). Perceived built environment and health-related quality of life in four types of neighborhoods in Xi'an, China. Health and Place, 39, 110-115.

Guan, C., Srinivasan, S., \& Nielsen, C. (2019) Does neighborhood form influence low-carbon transportation in China? Transportation and Research Part D: Transport and Environment 67, 406-420.

Guan, C., Srinivasan, S., Zhang, B., Da, L., Liu, J., \& Nielsen, C. (2020) The influence of neighborhood types on active transport in China's growing cities. Transportation and Research Part D: Transport and Environment 80, 102273. doi: 10.1016/j.trd.2020.102273

He, S., \& Lin, G. (2015). Producing and consuming China's new urban space: State, market and society, Urban Studies, 52(15), 2757-2773.

Hu, L., Yang, J., Yang, T., Tu, Y., \& Zhu, J. (2019). Urban spatial structure and travel in China. Journal of Planning Literature. Online first.

Kaufman, L., \& Rousseeuw, P. J. (1990). Finding groups in data. John Wiley \& Sons, New York, 1990. 
Krizek, K., Handy, S., \& Forsyth, A. (2009). Explaining changes in walking and bicycling behavior: Challenges for transportation research. Environment and Planning B 36: 725-740.

Lin, L. (2018). Leisure-time physical activity, objective urban neighborhood built environment, and overweight and obesity of Chinese school-age children. Journal of Transport \& Health. In press.

Lu, Y., Xiao, Y., \& Ye, Y. (2016). Urban density, diversity and design: Is more always better for walking? A study from Hong Kong. Preventive Medicine 103: S99-S103.

National Bureau of Statistics of China (2016). China statistical yearbook. China Statistics Press: Beijing.

National Resources Defense Council (2017). The China urban walkability report. https://www.nrdc.org/ china

Nilsson, I., \& Delmelle, E. (2018). Transit investments and neighborhood change: On the likelihood of change. Journal of Transport Geography, 66, 167-179.

Pan, H., Shen, Q., \& Zhang, M. (2009). Influence of urban form on travel behaviour in four neighborhoods of Shanghai. Urban Studies, 46(2), 275-294.

Pindyck, R., \& Rubinfeld, D. (1998). Econometric models and economic forecasts, 4th edition. New York: McGraw-Hill.

Qin, B. (2015). City profile: Chengdu. Cities, 43, 18-27.

Research Center for Contemporary China, Peking University. (2016). Chengdu Survey, 2016, The Sampling and Fieldwork Report. Collection of the authors.

Sakar, C., Webster, C., \& Gallacher, J. (2017). Association between adiposity outcomes and residential density: A full-data, cross-sectional analysis of 419562 UK Biobank adult participants. Lancet Planet Health 1: e277-288.

Shen, Y., Chai, Y., \& Kwan, M. (2015). Space-time fixity and flexibility of daily activities and the built environment: A case study of different types of communities in Beijing suburbs. Journal of Transport Geography, 47, 90-99.

Smith, M., Hosking, J., Woodward, A., Witten, K., MacMillan, A.,...Mackie, H. (2017). Systematic literature review of built environment effects on physical activity and active transport-an update and new findings on health equity. International Journal of Behavioral Nutrition and Physical Activity, 14, 158 (27pp).

Srinivasan, S., Guan, C., Nielsen, C. (2019) Built environment, income and travel behavior: Change in the city of Chengdu, China 2005-2016. International Journal of Sustainable Transportation 14(10), 749-760. doi: 10.1080/15568318.2019.1625088

$\mathrm{Su}, \mathrm{X}$. (2015) Urban entrepreneurialism and the commodification of heritage in China. Urban Studies, 52(15) 2874-2889. doi: 10.1177/0042098014528998

Wang, D., \& Chai, Y. (2009). The jobs-housing relationship and commuting to Beijing, China: The legacy of Danwei. Journal of Transport Geography 17, 30-38.

Wang, D., \& Zhou, M. (2017). The built environment and travel behavior in urban China: A literature review. Transportation Research Part D, 52, 574-585.

Wu, H., Chen, Y., \& Jiao, J. (2019). Impact of neighborhood built environments on shopping travel modes in Shanghai, China. Transportation Research Record, 2673(8), 669-681.

Yang, J. (2010). Spatial and social characteristics of urban transportation in Beijing. Transportation Research Record: Journal of the Transportation Research Board, 2193, 59-67.

Zhao, Y., \& Chai, Y. (2013). Residents' activity-travel behavior variation by communities in Beijing, China. Chinese Geographical Science, 23(4), 492-505.

Zhao, P., Lu, B., \& Roo, G. (2011). Impact of the jobs-housing balance on urban commuting in Beijing in the transformation era. Journal of Transport Geography, 19, 59-69. 